\title{
The Impact Of Information Technology Capability to A Company Agility
}

\author{
Erwin Permana ${ }^{1}$, Erna Maulina ${ }^{2}$, Margo Purnomo ${ }^{3}$, Achsanul Qosasi ${ }^{4}$, Asep \\ Miftahuddin 5 \\ ${ }^{12345}$ Faculty of Social and Political Science, Department of Business Administration, \\ Universitas Padjadjaran \\ win.buyung@gmail.com ${ }^{1}$, erna.maulina@unpad.ac.id ${ }^{2}$, purnomo@unpad.ac.id ${ }^{3}$, \\ achsanu1@indosat.net.id ${ }^{4}$, asep17012@mail.unpad.ac.id ${ }^{5}$
}

\begin{abstract}
The capability of ICT infrastructure has been proven to lead the process development and efficient activity management that could reduce the cost for the small company. This research was using the survey method. The results showed this research has managed to get the prove that the prime dimension that contributes the most in the formation of ICT capability is the ICT management, Proactive to ICT and Capability of ICT Infrastructure.
\end{abstract}

Keywords: Information Technology, Company Agility, business

\section{INTRODUCTION}

Every business player knows how volatile a market can be. There would not be any possible ways to stay in the market but to adapt to the volatility. Globalization, technology, and outsourcing have been named as the contributing parties to the uncertainty in the business market. Therefore, the adaptation ability of a company would be extremely critical [1]

Furthermore, it was stated that the situation above had brought another change, which was the major revisions in the business priorities, and strategic vision[2] citing [3].

The concept of agility is how a company would be able to adapt to the unforeseen changes. Agility itself is defined as the capability to move quickly. In the business term, the agile company could be considered as the company that can make a simple adjustment inside their system to be able to adapt with any unexpected or sudden changes in the business environment. The changes itself could be done in a very simple, rapid and efficient way [1][4].

Organization agility is relevant to the SMEs, considering that naturally, SMEs tend to have the ability to innovate, faster than the larger companies. This statement is relevant to the statement [5], [6]. Barney [7] Stated that the potential of information technology to provide firms with competitive advantage had been a topic of interest of practitioners and academics. Earlier, the development of information technology and communication capability would always be related to the infrastructure investment of the company. However, it was considered to be easily duplicated. Mata et al. [8] therefore stated the investment on the information technology and communication capability did not automatically direct the company to its competitive advantage.

Generally, those three dimensions of the information technology and communication, capability could be considered as connected one to the others and complemented one to the other as well, and at the same time, each of those gave the specific benefits to the organization. 
The impact of the information technology and communication to innovation has been considered as something important. This statement is confirmed by several studies. Johannessen et al. [9] stated in their quantitative study that the usage of information technology and communication has a positive impact on innovation and performance.

D. Gago and L. Rubalcaba [10] stated that the interaction between the different types of services innovation and the role of ICT is theoretically too strong to argue the opposite statement as a hypothesis. In many cases, ICT is (sic) not drivers but still facilitators of service innovations.

\section{METHOD}

This is a deductive research approach. This is an approach that was involving the theory verification through the hypothesis test to get the conclusion. This research method was taken to test a hypothesis in term of supporting it or on the contrary, rejecting it. This research could be categorized as explanatory research [11].

This research was using the survey method. It is a method that describes the trends, behaviors, or opinions of a population quantitatively by analyzing the population's sample and generate generalization or prove the claims on the population [12]. The researchers used the quantitative method where systematically the same questions were being asked to all samples, and all answers were recorded [13].

This research's paradigm is positivism or quantitative. This paradigm tries to search for the facts or the social phenomena to find the new concept, by developing a hypothesis in the beginning, which would be used onto a certain population and sample, data collection by using the research instruments, statistical tests and taking general conclusion[14]. This research is analyzing the connection between the information technology and communication capability of an organization to its agility. This research was conducted between April to June 2018 .

The research was being delivered to the SMEs of Fashion in the traditional markets which are managed by PD Pasar Jaya, Jakarta, Indonesia. The unit analysis of this research should be those that are: 1) listed as the Fashion SME in the traditional market in Jakarta, 2)should have used the information technology and communication in their daily operational activities, 3) fulfilled the criteria as the micro business on fashion under the Act No 20 the year 2008 on Micro, Small and Medium Enterprise that has asset more than 50 million to 500 million (rupiahs) and it should have 00 million to 2,5 billion turnovers per year. Based on those criteria, this research has the 12.455 business in the population.

Furthermore, this research used a random sampling method. It was chosen with two consideration. First, each of the members of the population has the same chance to be involved as a sample. Second, this research was only focusing on the micro business in the fashion zone of the traditional markets that were managed by PD Pasar Jaya. Slovin formula was being used to determine the amount of the sample.

Table 1. Data from the Traditional Market - Fashion Zone

\begin{tabular}{llccc}
\hline & & \multicolumn{3}{c}{ Textile Business Type } \\
No & Market Name & Total & Fabric & Apparel \\
\cline { 3 - 4 } & & & & \\
\cline { 3 - 4 } & & & & \\
\hline 1 & Pasar Tanah Abang & 14796 & 5918 & 8878 \\
\hline
\end{tabular}




\begin{tabular}{llccc}
\hline 2 & Pasar Jatinegara & 1334 & 534 & 800 \\
\hline 3 & Pasar Cipulir & 3210 & 1284 & 1926 \\
\hline 4 & Pasar Mayestik & 358 & 143 & 215 \\
\hline 5 & Pasar Blok M Square & 1060 & 424 & 636 \\
\hline & & Total Apparel & & 12455 \\
\hline
\end{tabular}

$$
\mathrm{n}=\frac{\mathrm{N}}{1+\mathrm{N} d^{2}}=\frac{12455}{1+(12455)(0.05)^{2}}=387,55=388
$$

Where:

$$
\mathbf{n}=\text { Sample Size } \quad \mathbf{N}=\text { Population } \quad \mathbf{d}=\text { Precise Value }
$$

The size of the population was N. N size $=12.455$. Based on the confidence at $95 \%, d=0.0025$. The sampe $(\mathrm{n})=377,55 \sim \mathbf{3 8 8}$.

Data and the data sources for this research were the primary data. It was taken directly from the source and being taken by getting the answers of the research questions, as what it was determined by the research. The primary data in this research were the social profile and respondents identifications. These data consist of gender, age, status, and highest education of the respondents, address and the profile of the business itself.

The representation of the sample in research is a very important thing to be able to generalize. The researcher has decided to use Structural Equation Modelling. SEM covariant based would require the large size of the sample that could be hundreds or thousands. However, this research used the PLS-SEM that only required smaller sample size. The minimum sample size for this research was 10x largest formative indicators that were being used to measure one latent variable or 10x from the largest structural line size that was directed to a certain latent variable in the structural model. Based on those, the sample size for this research was 388 micro business in the traditional markets managed by PD Pasar Jaya.

To collect the data, the researcher chose to use two methods. First by using library research to get information from any related documents, and second, by doing the field research to get the primary data and the exact information from the field, by distributing the questioners.

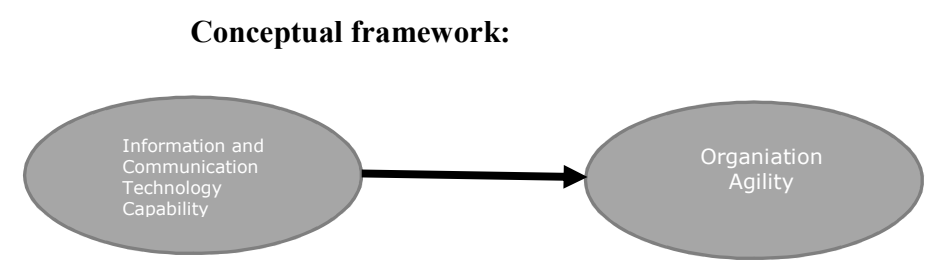

Research Hypothesis: ICT capability has a significant effect on organizational agility. 


\section{RESULT AND DISCUSSION}

The research used the Structural Equation Modelling with Partial Least Square (PLS). There were three steps that should be done in this analysis, which are: outer model analysis, inner model analysis, and hypothesis test.

\subsection{Outer Model Analysis}

Table 3. Cronbach Alpha, Composite Reliability Dan Average Variance Axtracted

\begin{tabular}{|c|c|c|c|c|}
\hline & $\begin{array}{l}\text { Cut-off } \\
\text { Value }\end{array}$ & $\underset{\text { ty }}{\text { Bus_Agili }}$ & Kap_TIK & Keterangan \\
\hline $\begin{array}{l}\text { Cronbach's } \\
\text { Alpha }\end{array}$ & $>0.6$ & 0,920 & 0,939 & \multirow{3}{*}{$\begin{array}{l}\text { All aspect of } \\
\text { the smes of } \\
\text { fashion } \\
\text { fulfilled the } \\
\text { standard }\end{array}$} \\
\hline $\begin{array}{l}\text { Composite } \\
\text { Reliability } \\
\end{array}$ & $>0.7$ & 0.960 & 0.969 & \\
\hline $\begin{array}{l}\text { Average } \\
\text { Variance } \\
\text { Extracted } \\
(\text { AVE })\end{array}$ & $>0.5$ & 0.949 & 0,961 & \\
\hline
\end{tabular}

According to [15], in the reliability test, the construct measured by the composite reliability and Cronbach's alpha. Construct would be stated as reliable if it was higher than 0,70 and Cronbach's alpha above 0,60 . The Average Variance extracted that would be suitable was 0.5 . Based on that statement above, the whole criteria of the outer model were fulfilled, so it could be considered that this research is valid and reliable.

\subsection{Inner Model Analysis}

This is important to ensure that the built structural model was robust and accurate. The inner model analysis would be consisting of several indicators; coefficient determination $\left(\mathrm{R}^{2}\right)$, Predictive Relevance $\left(\mathrm{Q}^{2}\right)$, Goodness of Fit Index (GoF), respectively: 0.87; 0.995; and 0.77.

\subsection{Hypothesis Test}

To test the hypothesis, the researcher used the bootstrapping process to get an equal variance assumed. If it is higher than the table, with the confidence interval level higher than $95 \%$, the hypothesis would be significant.

Table 4. Path Coefficients (Mean, STDEV, t-Value)

\begin{tabular}{lccccc}
\hline \multicolumn{1}{c}{ Hipotesis } & $\begin{array}{l}\text { Original } \\
\text { Sample }(\mathrm{O})\end{array}$ & $\begin{array}{l}\text { Sample } \\
\text { Mean }(\mathrm{M})\end{array}$ & $\begin{array}{l}\text { Standard } \\
\text { Deviation } \\
(\text { STDEV) }\end{array}$ & $\begin{array}{c}\text { T Statistics } \\
(|\mathrm{O} / \mathrm{STDEV}|)\end{array}$ & $\begin{array}{c}\mathrm{P} \\
\text { Values }\end{array}$ \\
\hline $\begin{array}{l}\text { Kapabilitas TIK-> } \\
\text { Business agility }\end{array}$ & 0,604 & 0,602 & 0,061 & 10,590 & 0,000 \\
\hline
\end{tabular}

Source: Output SmartPLS, 2019

Based on the calculation above the Hypothesis on the Impact of ICT Capability to the Business Agility was accepted. The original sample estimate Loading factor as 0.604 with 
significance under $5 \%$ which was shown by the t-stat 6.590 higher than the t-table 1.962 . It indicates that ICT capability has a positive impact on business agility.

The result is in line with earlier research [16]. It was stated that ICT capability has a positive impact on the agility of the business. The ICT capability would impact the agility because by having the ICT capability, it would give the organization more business chances, connections with customers and more resources.

Referring to the survey result, it is shown that the adopted technology was the smartphone, laptops, and computers.

Table 4. The technology used by respondents

\begin{tabular}{lrr}
\hline Adopted Tech & Qty & \multicolumn{2}{c}{ Rate } \\
\hline Smartphone & 440 & $95 \%$ \\
\hline Laptop & 14 & $3 \%$ \\
\hline computer & 8 & $2 \%$ \\
\hline Total & 462 & $100 \%$ \\
\hline
\end{tabular}

The communication media options in this research are mostly the simple internet media such as social media which consists of Facebook, Instagram, Line. Some of the business were using websites (small numbers of them).

Table 5. Adopted Digital Communication Media

\begin{tabular}{lrr}
\hline Types & Qty & \multicolumn{2}{c}{ Rate } \\
\hline Social Media (WA IG, FB, Line, Etc) & 426 & $92 \%$ \\
\hline Website & 36 & $8 \%$ \\
\hline Total & 462 & 100 \\
\hline
\end{tabular}

From the literature review of ICT, there would be three aspects that have been identified: 1)The capability of ICT Infrastructure; 2) Capability of the ICT Management; and 3) the Proactive to the ICT [17]-[21].

1) The capability of ICT infrastructure has been proven to lead the process development and efficient activity management that could reduce the cost for the small company. The company could also develop their document management by using the software or apps and get the benefits by managing the communication to the stakeholder, including to the internal management such as employees or the external parties such as suppliers. The companies also have been involving the social media network such as Whatsapp, Facebook, line, etc that would help them to achieve internal efficiency [22].

2) The Management of ICT refers to management ICT to improve the performance of the company. It would include the integration of the business plan and the ICT plan that would be used, managed and adopted the ICT to simplify the information sharing among employees. The company that used ICT and educate the employees about the benefits of company relations by using ICT. Company with the strong ICT capability would be able to give the special service to their partners with the more punctual delivery, high-quality communication, etc. All of those services would bring trust, satisfaction, and commitment to maintain a good relationship. 
3) Proactive to the ICT is by being able to take the optimum benefits by finding the innovations of the company. The usage of ICT has a positive impact on the communication between the company and the partners [23]

It would also give the consistent in and out information flow, that would give the chances to the company to learn and do some researches for the better business result [24].

Based on the primary data running, we could see that the prime dimension that contributes the most in the formation of ICT capability is the ICT management with $96.1 \%$, Proactive to ICT $94,2 \%$ and Capability of ICT Infrastructure $87,9 \%$.

\section{CONCLUSION}

This research has managed to get the proof that the prime dimension that contributes the most in the formation of ICT capability is the ICT management with $96.1 \%$, Proactive to ICT $94,2 \%$ and The capability of ICT Infrastructure $87,9 \%$. The ICT usage in the micro business was limited to social media for product marketing. There were very small numbers of the business owners that have already developed websites for their business, especially to be used as e-commerce media. This situation has a significant impact on business agility.

This research proved that the micro business has an operational agility $96.1 \%$ and market agility $96,6 \%$. Small business would have the highest possibilities to take aggressive steps and agile in the market.

\section{REFERENCES}

[1] A. Ganguly, R. Nilchiani, and J. V. Farr, "Evaluating agility in corporate enterprises," Int. J. Prod. Econ., vol. 118, no. 2, pp. 410-423, 2009.

[2] Y. H. Tseng and C. T. Lin, "Enhancing enterprise agility by deploying agile drivers, capabilities and providers," Inf. Sci. (Ny)., vol. 181, no. 17, pp. 3693-3708, 2011.

[3] Z. Zhang and H. Sharifi, "A methodology for achieving agility in manufacturing organisations," Int. J. Oper. Prod. Manag., vol. 20, no. 4, pp. 496-513, 2000.

[4] N. C. Tsourveloudis and K. P. Valavanis, "On the measurement of enterprise agility," J. Intell. Robot. Syst. Theory Appl., vol. 33, no. 3, pp. 329-342, 2002.

[5] Y. Lu and K. R. Ramamurthy, "Understanding the Link Between Information Technology Capability and Organizational Agility: An Empirical Examination," Manag. Inf. Syst. Res. Center, Univ. Minnesota, vol. 35, no. 4, pp. 931-954, 2011.

[6] S. Goldman, R. Nagel, and K. Preiss, Agile Competitors and Virtual Organizations. New York: Van Nostrand Reinhold, 1995.

[7] J. Barney, "Firm Resources and Sustained Competitive Advantage," J. Manage., vol. 17, no. 1, pp. 99-120, Mar. 1991.

[8] F. J. Mata, W. L. Fuerst, and J. B. Barney, "Information technology and sustained competitive advantage'," MIS Quarterly, December, vol. 19, no. 4, pp. 487-505, 1995.

[9] J.-A. Johanessen, J. Olaisen, and B. Olsen, "Systemic Thinking as the Philosophical Foundation for Knowledge Management and Organizational Learning," Kybernetes, vol. 28, pp. 24-46, 1999.

[10] D. Gago and L. Rubalcaba, "Innovation and ICT in service firms: Towards a multidimensional approach for impact assessment," J. Evol. Econ., vol. 17, no. 1, pp. 25-44, 2007. 
[11] P. D. Leedy and J. E. Ormrod, Practical Research. Pearson Custom, 2005.

[12] J. Cresswell, Handbook of Mixed Methods in Social and Behavioral Research. Thousand Oaks: SAGE, 2010.

[13] W. L. Newman, Social Research Methods: Qualitative and Quantitative Approaches, Seventh. Pearson International, 2013.

[14] F. Wollenschläger, "A new fundamental freedom beyond market integration: Union citizenship and its dynamics for shifting the economic paradigm of European integration," Eur. Law J., vol. 17, no. 1, pp. 1-34, 2011.

[15] W. W. Chin, Quantitative Method Series: Modern Methods for Business Research Chapter 10 - The Partial Least Square Approach to Structural Equation Modeling. New Jersey: Lawrence Erlbaum Associates, Inc, 1998.

[16] N. M. Yaghoobi, M. Bakhshimazdeh, and M. Alikhasi, "Analysing key concepts of organisation: knowledge management, competitive intelligence and competitive advantage," Int. J. Serv. Oper. Manag., vol. 18, no. 3, p. 321, 2014.

[17] A. S. Bharadwaj, "A Resoure-Based Perspective on Information Technology Capability and Firm Performance : An Empirical Investigation," MIS Q., vol. 24, no. 1, pp. 169196, 2000.

[18] A. Bharadwaj, V. Sambamurthy, and R. W. Zmud, "IT capabilities: theoretical perspectives and empirical operationalization," Manage. Sci., vol. Charlotte, no. January, pp. 378-385, 1999.

[19] V. Sambamurty, A. Bharadwaj, and V. Grover, "Shaping Agility through Digital Options; Reconceptualizing the Role of Information Technology in Contemporary Firms," Manag. Inf. Syst. Res. Center, Univ. Minnesota, vol. 27, no. 2, pp. 237-263, 2003.

[20] M. J. Lyver and T.-J. Lu, "Strategic Entrepreneurship' s Impact on Product Innovation Performance: An Analysis of ICT Firms," Acad. Manag., vol. 2017, no. 1, p. 2017, 2017.

[21] P. H. Schwager, T. A. Byrd, and D. E. Turner, "Information technology infrastructure capability $\hat{\mathrm{a}} €^{\mathrm{TM}} \mathrm{s}$ impact on firm financial perfomance: An exploratory study," $J$. Comput. Inf. Syst., vol. 4417, no. February, pp. 98-105, 2000.

[22] C. Guo and M. Acar, "Understanding collaboration among nonprofit organizations: Combining resource dependency, institutional, and network perspectives," Nonprofit Volunt. Sect. Q., vol. 34, no. 3, pp. 340-361, 2005.

[23] M. Sarshar and U. Isikdag, "A survey of ICT use in the Turkish construction industry," Eng. Constr. Archit. Manag., vol. 11, no. 4, pp. 238-247, 2004.

[24] N. Venkatraman, "It-Enabled Business Transformation - From Automation To Business Scope Redefinition," Sloan Manage. Rev., vol. 35, no. 2, pp. 73-87, 1994. 